Abstracta Iranicacta Iranica

Revue bibliographique pour le domaine irano-aryen

Volume 40-41 | 2019

Comptes rendus des publications de 2017-2018

\title{
Andrea Gariboldi. Sasanian Coins and their Imitations from Sogdiana and Tocharistan
}

\section{Rika Gyselen}

\section{(2) OpenEdition \\ 1 Journals}

\section{Édition électronique}

URL : http://journals.openedition.org/abstractairanica/49622

DOI : 10.4000/abstractairanica.49622

ISBN : 1961-960X

ISSN : 1961-960X

Éditeur :

CNRS (UMR 7528 Mondes iraniens et indiens), Éditions de l'IFRI

Référence électronique

Rika Gyselen, «Andrea Gariboldi. Sasanian Coins and their Imitations from Sogdiana and Tocharistan », Abstracta Iranica [En ligne], Volume 40-41 | 2019, document 21, mis en ligne le 30 octobre 2019, consulté le 19 avril 2021. URL : http://journals.openedition.org/abstractairanica/49622 ; DOI : https:// doi.org/10.4000/abstractairanica.49622

Ce document a été généré automatiquement le 19 avril 2021.

Tous droits réservés 


\title{
Andrea Gariboldi. Sasanian Coins and their Imitations from Sogdiana and Tocharistan
}

\author{
Rika Gyselen
}

\section{RÉFÉRENCE}

Andrea Gariboldi. Sasanian Coins and their Imitations from Sogdiana and Tocharistan. Wien: Verlag der Österreichischen Akademie der Wissenschaften, 2017. 189 p. (Sylloge Nummorum Sasanidarum Tajikistan)

1 Le catalogue sous forme de sylloge (p. 56-174) comporte 708 monnaies dont 32 sassanides (26 appartiennent au trésor monétaire trouvé en 1950 à Dushanbe), 8 arabosassanides et arabo-hephtalites, 262 monnaies de Bukharkhudat et 406 des Huns iraniens. Ces derniers proviennent essentiellement d'un trésor monétaire trouvé à Čorgul'tepa conservé au musée de l'Ermitage à Saint-Pétersbourg.

Une des discussions est consacrée aux monnaies arabo-hephtalites n³3 et n³4, un type extrêmement rare, pour lesquelles N. Sims-Williams a proposé une lecture de la légende marginale au revers qui est essentiellement bactrienne (p. 26-27). Plusieurs pages sont consacrées à l'étude des monnaies de Bukharkhudat qui imitaient les monnaies sassanides de Wahrām $V$ et qui représentent une série monétaire produite en Sogdiane au moins pendant quatre siècles (p. 27-35). 


\section{AUTEURS}

\section{RIKA GYSELEN}

CNRS, Mondes iranien et indien 